\title{
ENTREVISTA COM LUIZ EDUARDO SOARES
}

\section{Introducão do coordenador da entrevista}

\section{Carlos Alberto Steil}

No Espaço Aberto deste número, Horizontes Antropológicos traz uma entrevista com o antropólogo e cientista político Luiz Eduardo Soares, destacando sua reflexão sobre a experiência à frente da Secretaria de Segurança Pública do Rio de Janeiro, como seu Subsecretário, no período de janeiro de 1999 até sua demissão, em março de 2000. A iniciativa partiu do organizador deste número de HA, que fez o convite a Luiz Eduardo Soares, quando ainda morava em Nova Iorque, que gentilmente se dispôs a colaborar com a revista. Tanto para o organizador quanto para o entrevistado, este espaço surgiu como uma oportunidade importante para expor uma reflexão sobre a relação entre ciência e política, a partir da experiência concreta de um antropólogo e cientista político no poder.

O meio para viabilizar a entrevista foi a rede eletrônica. Através de uma troca contínua de e-mails, no decorrer do segundo semestre de 2000 e dos primeiros meses deste ano, entre o organizador do número e o entrevistado, estabeleceram-se as bases sobre as quais seria realizada a entrevista e definiu-se uma lista de cientistas sociais que, em nossa avaliação, teriam uma contribuição importante a oferecer para que a entrevista pudesse abordar questões relevantes para as ciências sociais. O critério de escolha era que se tratassem de pesquisadores familiarizados com o tema da segurança pública no campo das ciências sociais ou que, nos últimos anos, tivessem acompanhado mais de perto a trajetória acadêmica e política de Luiz Eduardo Soares. A lista dos entrevistadores no início era bem mais extensa do que os que efetivamente vieram a participar da entrevista. Mas, temos certeza de que aqueles que responderam ao nosso convite são bastante representativos e elaboraram um rol de questões extremamente pertinentes sobre o tema.

Participaram da entrevista, enviando suas perguntas por e-mail, os seguintes entrevistadores: João Trajano Sento-Sé, cientista político e coor- 
denador do Programa de Pós-Graduação em Ciências Sociais da Universidade Estadual do Rio de Janeiro (UERJ); Otávio Guilherme Alves Velho, antropólogo e coordenador do Programa de Pós-Graduação em Antropologia do Museu Nacional da Universidade Federal do Rio de Janeiro (UFRJ); Gustavo Lins Ribeiro, antropólogo e coordenador do Programa de PósGraduação em Antropologia da Universidade de Brasília (UnB); Rita Laura Segato, antropóloga da Universidade de Brasília (UnB); Hélio Silva, antropólogo e coordenador do Programa de Pós-Graduação em Ciências Sociais da Pontifícia Universidade Católica do Rio Grande do Sul (PUC/ RS) e Ruben George Oliven, antropólogo da Universidade Federal do Rio Grande do Sul (UFRGS) e presidente da Associação Brasileira de Antropologia (ABA). Como organizador deste número de HA, gostaria de agradecer a colaboração de todos, primeiramente de Luiz Eduardo Soares, que tão gentilmente cedeu ao nosso convite, e dos entrevistadores, que nas duas rodadas da entrevista, se dispuseram a formular suas questões com muita competência e franqueza.

\section{Entrevista}

Luiz Eduardo: Antes de iniciar a entrevista propriamente dita, gostaria de agradecer aos colegas que formularam as perguntas, aos editores da Revista Horizontes Antropológicos e, muito especialmente, ao professor Carlos Alberto Steil, pela iniciativa e pela coordenação da entrevista. Essa oportunidade, além de representar um privilégio, pela atenção que mereci de profissionais que admiro, eu a valorizo como um momento raro de diálogo do qual sou o principal beneficiário.

\section{João Irajano Sento-Sé}

João: Embora sua trajetória pessoal e intelectual tenha estado sempre marcada por uma intensa militância política, a passagem pelo governo Garotinho foi, salvo engano, sua primeira participação direta em um setor de gestão de políticas públicas. Meses depois de sua saída, quais seriam os aspectos a serem destacados dessa experiência, caso você decidisse escrever um ensaio etnográfico sobre ela? 
Luiz Eduardo: Nós temos nos preparado pouco, na academia, na universidade, mesmo na pós-graduação, e temos preparado nossos alunos insuficientemente para enfrentar esse desafio tremendo: a necessidade de conceber e implantar políticas públicas de segurança, em contextos políticos complicados. Além disso, conhecemos muito menos do que deveríamos as instituições que operam na área, nas suas múltiplas dimensões. Somos razoáveis no diagnóstico, mas quase nulos na esfera propositiva. Essa negligência nossa, a despeito dos esforços admiráveis e mais ou menos isolados de uns poucos, deixa o espaço livre para que a inércia realize o trabalho de perpetuar as irracionalidades, a desorganização e a barbárie. A inércia cumpre seu papel, aliada ao conservadorismo político e ao corporativismo estreito das polícias.

João: Pode-se dizer, em linhas gerais, que a antropologia foi um campo de conhecimento formado pelo esforço de construção de narrativas que conferem alguma margem de inteligibilidade ao Outro, daí sua quase inigualável dimensão crítica e, mais recentemente, autocrítica. Como é possível e quais as dificuldades de colocar esse patrimônio intelectual a serviço da rotina própria à política governamental em uma área tão sensível e cheia de surpresas como a segurança pública?

Luiz Eduardo: Essa resposta exige toda uma vida de reflexão. É tema para mais de um livro, para toda uma obra. No entanto, para não fugir à fraterna provocação, eu diria que os antropólogos podem contribuir, nessa área, convocando a participação popular, conduzindo-a e interpretando-a com as nuances e a profundidade necessárias. Também podemos colaborar analisando os aspectos ligados às micro-políticas, aos valores em choque e às culturas organizacionais. Ou chamando a atenção para as dimensões simbólicas, inconscientes, afetivas e inter-subjetivas da segurança e de sua percepção social, entendida como a estabilização de expectativas, geradora de profecias que se autocumprem. No mínimo, a focalização dessas dimensões, se for competente, nos levará a defender uma nova estratégia de comunicação das autoridades policiais com o grande público, através da mídia, escapando à desgastada postura defensiva. Tematizo extensamente esse ponto no livro que acabo de publicar, Мeu Casaco de General: 500 Dias no Front da Segurança Pública do Rio de Janeiro (Cia. das Letras, 2000). 
João: Não é de todo implausível que, após a comoção inicial em torno de sua saída do governo, alguns cidadãos fluminenses, frustrados e temendo pelos rumos da política de segurança no estado, atribuíssem à sua atitude final um certo jacobinismo. À luz de sua experiência no governo e do desenlace frustrante para a população fluminense, você diria que a ética da convicção é, de fato, incompatível com o princípio da responsabilidade na política?

Luiz Eduardo: Acho que as alianças na área da segurança e a ética da responsabilidade são problemas sempre abertos, sempre repostos, por sua importância, por sua dificuldade e pelas variações imensas que cada contexto determina. Impossível estabelecer uma regra geral e única. Vou começar com as alianças. Focalizando o caso da segurança pública do Rio de Janeiro, eu diria que há três grupos, grosso modo, nas polícias: (1) aquele composto por profissionais sérios, de ideologias e concepções profissionais diversas; (2) aquele composto por criminosos; e, finalmente, (3) aquele segmento vasto e difícil de delimitar, que costuma, também grosso modo, dançar conforme a música, aderindo a práticas criminosas ou afastando-se delas, de acordo com a postura da liderança, com a atenção crítica da sociedade ou com a existência e eficiência de mecanismos internos e externos de controle.

Sendo assim, sempre grosso modo, eu diria que o comportamento que me parece o mais recomendável e que eu procurei seguir é o seguinte: (a) aliar-se ao grupo número um, com o máximo de tolerância para a diversidade, pois ela é menos importante que a união em torno da seriedade profissional, sem o que nenhuma política de segurança é possível; (b) isolar os criminosos e procurar combatê-los; (c) tentar atrair os setores intermediários, premiando-os pelo bom comportamento, conversando muito, procurando conquistá-los para um projeto que lhes recupere a autoestima, valorizando-os, mas também marcando com firmeza os limites, estabelecendo mecanismos de controle externo e interno. Nada, entretanto, funciona para valer se não houver o apoio do governador e de pelo menos parte expressiva da opinião pública, da sociedade civil, dos movimentos sociais, dos sindicatos, etc. É importante também o envolvimento positivo das forças políticas, particularmente dos partidos da base de sustentação do governo. 
Era essa a minha orientação e para isso me reunia, constantemente, com policiais de todas as patentes, com políticos, empresários, associações, sindicatos, mídia, etc. E as coisas estavam indo razoavelmente bem, sem grandes traumas internos à corporação, com muita negociação para cada passo, até que a mudança de eixo político do governo, ou melhor, do governador, levou-o a uma reavaliação e o conduziu a uma opção diferente, que se traduziu na mudança da chefia da polícia civil, no dia 13 de dezembro de 1999. Essa aliança eu não poderia aceitar, pois ela inviabilizaria qualquer processo de reforma, por mais moderado que fosse.

Eu sairia do governo nesse dia, não fosse a campanha da Folha de São Paulo contra o projeto Delegacia Legal, através de acusações de superfaturamento, como relato no livro. Garotinho moveu as peças daquela forma e naquele momento, porque sabia que minhas mãos estavam amarradas. Se eu me demitisse, ele diria que me exonerou por suspeita de corrupção e minha vida estaria arruinada. Só me restou ganhar tempo, superar aquele momento, deixar claro que a acusação contra a delegacia legal era falsa e, já que teria de estender de qualquer jeito a permanência no governo, aproveitar para tentar reverter aquela decisão política do Garotinho, que redefinia nossa estratégia. Tentei a persuasão, a pressão direta, a pressão indireta via mídia e sociedade, até o extremo do confronto, em que jogava com pouquíssimas chances de sucesso. Mesmo sendo improvável, a radicalização era preferível à renúncia, como acho que o futuro comprovou.

Ou seja, a estratégia natural foi abortada contra minha vontade em 13 de dezembro de 1999 e, a partir daí, só me restava buscar soluções de resistência, ante um quadro que já me derrotara.

Deduz-se desse relato minha visão da dicotomia weberiana "convicção-responsabilidade". Considero inviável uma formalização positivista e cientificizante do dilema que acabo de descrever, ou seja, creio ser impossível ponderar matematicamente os valores relativos de cada hipótese: (a) fortalecer o governador e fortalecer-me no cargo, buscando aplicar uma estratégia "incremental", gradualista, aceitando o recuo tático e as novas alianças que vieram a bordo no dia 13 de dezembro de 1999, sacrificando provisoriamente os projetos e, portanto, a política de segurança, para, se possível, retomá-la adiante, em nova conjuntura [sob o risco de servir de instrumento de legitimação a uma política de segurança que sempre com- 
bati; aceitar conviver com práticas corruptas e genocidas; perder crescentemente a possibilidade de retomar o fio da meada da nova política que começara a implantar; desmoralizar-me; coonestar a hipocrisia que chama de nova a velha política; endossar as velhas práticas do fisiologismo e do oportunismo político, ajudando o governador, por meu silêncio e minha continuada aliança, a fortalecer seu cacife no plano nacional, credenciando-se a competir pela representação das forças de esquerda, pondo em risco a seriedade dos projetos progressistas.]; (b) criar condições para que minha eventual continuidade no cargo só fosse possível nos termos expressos acima, na exposição sobre a política de alianças que considero aceitável, uma vez que incorporar o grupo número 2 implicaria a inviabilização da política de segurança que constituía a razão mesma de minha presença no governo.

Optei pela hipótese (b). Na ausência de cálculo matemático, restam as interpretações. Considerei prováveis os riscos que associei à hipótese (a) e verdadeiro o enunciado positivo da hipótese (b), segundo a qual alianças com o segmento número 2 da polícia constituiria impedimento objetivo e insuperável para a implantação de qualquer política de segurança decente e defensável (ou de suas variações). Nesse caso, portanto, creio que a postura responsável era ater-me, com o indispensável e também weberiano senso de medida, às convicções. Infelizmente, a idéia de responsabilidade tem sido vulgarizada e reduzida a sinônimo do oportunismo mais medíocre. A contrapartida dessa perversão tem sido a desqualificação in limine da adesão às convicções, como se convicções, necessariamente, implicassem sectarismo, principismo ou dogmatismo. Quando é que você leu ou ouviu, pela última vez, uma referência a essa dicotomia weberiana em que se privilegiasse o polo da convicção? Duvido que você se lembre. Não há. Ainda que a intenção de Weber fosse outra, essa díade só tem servido à racionalização e à justificação de atitudes que consideramos anti-éticas, cujo móvel é a cooptação e a permanência nos cargos de poder a qualquer custo, em nome das virtudes da prudência, da moderação, da paciência, que antecipariam o amadurecimento gradual das metas - paradoxalmente, sempre adiadas.

João: Até o presente momento, o governo Garotinho não conseguiu recuperar a credibilidade perdida quando de sua saída da Secretaria de Segurança Pública. Você teria algo a comentar acerca dos processos pelos quais 
um conjunto de valores, expectativas e projetos compartilhados amplamente adere a uma certa personalidade pública, de modo que sua ausência leve a uma espécie de vácuo simbólico e a uma frustração política?

Luiz Eduardo: Acho que talvez não se trate de nenhum processo complexo e de difícil compreensão a desestabilização da imagem do governador, em certos estratos da população (deixo de lado, provisoriamente, a questão relativa à minha imagem e à sua relação com determinada política). Os segmentos mais informados da opinião pública fluminense talvez conhecessem razoavelmente e se identificassem com as idéias simples, ainda que inusuais, que eu defendia. Esses segmentos talvez valorizassem o apoio audacioso, criativo e original do governador às novas iniciativas, inspiradas nessas idéias. Nós começamos a desenhar uma identidade política libertária e, ao mesmo tempo, comprometida com a ordem pública democrática, implementada de modo mais racional e transparente, e menos reativo, voluntarista, arrogante e dispersivo. Era uma combinação nova de posturas e vocabulários. Idéias, mesmo muito simples, quando dotadas de um mínimo de consistência, assumem um peso surpreendente, quando o campo imaginário, discursivo e comunicacional em que prosperam é marcado por um léxico pobre, desgastado e repetitivo, que soa falso e equivocado a qualquer observador minimamente crítico. Esse segmento pequeno mas influente da opinião pública viu claramente, quando fui demitido, que o rei estava nu, isto é, que o governador não tinha nenhum compromisso com aquelas novas posturas, práticas e discursos, para além das conveniências políticas do momento. A desilusão com o governador foi muito rápida porque, sob a boa imagem construída com esforço ao longo do primeiro ano de governo, ainda restavam os traços negativos do radialista de Campos (inconfiabilidade, populismo inconsistente, voluntarismo, volubilidade, oportunismo, superficialidade, despreparo), identificados por esses setores da opinião pública na pessoa do então candidato ao governo do estado, por ocasião da campanha de 1998, e que custou ao atual governador a derrota para seu oponente na capital, naquela oportunidade (reeditada, na disputa pela prefeitura, no ano 2000, na qual foi derrotado o candidato do PFL, apoiado pelo governador). Eu estava entre aqueles que acreditaram que esses traços não passavam de acusações interessadas e injustas. Ou seja, acho que não houve uma súbita mudança de imagem do governador, no 
episódio de minha demissão, mas uma reatualização de percepções que existiam mas estavam encobertas ou em processo de redefinição.

Quanto à minha imagem, não conheço detalhes de pesquisas de opinião, mas ousaria dizer que talvez os aspectos positivos que porventura houver derivam das idéias e valores, mas também, do fato de que provoquei um estranhamento, por ter sempre procurado dizer a verdade, sendo franco e parecendo franco, mesmo quando a verdade ou minha visão dela era negativa para mim mesmo e para o governo de que fazia parte. Estou convencido de que a população tem uma incrível capacidade de ser generosa, compreensiva e de perdoar, de dar novas chances, de entender as dificuldades e de relevar erros, desde que sinta confiança no agente, em sua postura, em seu discurso, em sua prática e em seus compromissos. Por isso, me parece equivocada, não só eticamente, mas também politicamente, a idéia de que é preciso mentir, enganar e dourar a pílula para defender e proteger o governo. A população intui a mentira e não suporta mais os velhos truques da retórica evasiva, falsa, artificial. Acho que a gente tem a obrigação de resistir às armadilhas do poder, que estende sua lógica reificadora e acaba moendo tudo e todos, atropelando a diversidade de valores. Acho que nós, que desejamos ser herdeiros de algo que talvez se pudesse denominar socialismo humanista, temos a obrigação de tentar antecipar, hoje, em nossa prática atual, uma sociabilidade e uma postura ética compatíveis com a sociedade futura por que lutamos.

João: A participação de intelectuais em certas áreas de governo é bastante comum no Brasil. Isso, todavia, não se dá no campo da segurança pública. A que você atribuiria essa dificuldade de colaboração e quais as perspectivas futuras para que ela se dê?

Luiz Eduardo: O professor Gláucio Ari Dillon Soares certa vez me disse que eu estava pagando o preço pela abertura de um espaço e pelo estabelecimento de uma relação que, no futuro próximo, se tornaria freqüente e natural. Tenho certeza de que ele tinha razão. Em breve, vamos rir dessas resistências todas. Porém, hoje, ainda há um preconceito duplo: nós olhamos os policiais com desconfiança, desdém e superioridade, e eles (ou elas) retribuem na mesma moeda. Por que há poucos intelectuais na área de segurança dos governos? Por conta das consequiências desse nosso preconceito e pela negligência que eu acho que é, a um só tempo, ético-

Horizontes Antropológicos, Porto Alegre, ano 7, n. 15, p. 239-270, julho de 2001 
política e intelectual: nós lavamos as mãos e não queremos nos conspurcar com esse campo minado - física e moralmente (conta)minado. Não queremos nos sujar com esses temas que parecem menores. Esquecemos que nossos pais fundadores, de Hobbes a Rousseau, formularam suas teorias sociais e políticas pensando a segurança pública e a partir dela, entendida como estabilização de expectativas, redutora político-cultural-interativainter-subjetiva da incerteza. Nós nos esquecemos que a invisível partícula elementar da ordem social é a confiança e que devemos a ela a autoridade, a legitimidade das instituições, a paz, a acumulação evolucionária ou civilizatória, a "prosperidade", a previsibilidade razoável dos encontros humanos e a relativa redução de nossa experiência da tragédia e da angústia, isto é, o razoável controle de nossa vivência da temporalidade e da alteridade (da diferença, da diferenciação/complexificação ou da mudança) como indeterminação, risco e antecipação da morte. Nós nos esquecemos que a problemática da segurança é nobre e está no coração de nossas mais caras tradições. Por outro lado, infelizmente, tampouco nos sensibiliza a dramaticidade dos problemas empíricos que nos cercam.

\section{Otávio Velho}

Otávio: A temática da segurança vem se impondo, hoje, para as ciências sociais. De certa forma isso foi uma vitoria para quem, como você, tem insistido na necessidade de nosso trabalho ser relevante política e socialmente. Agora, numa nova volta do parafuso, pergunto-lhe se não teme que a linguagem da segurança possa dominar de tal maneira nossos estudos, como engendradora de questões e, mesmo, fonte de metáforas, que corram o risco de perder outras maneiras de olhar para a sociedade, empobrecendo-se e mesmo produzindo um perigoso viés.

Luiz Eduardo: Concordo inteiramente com sua preocupação e a considero da maior relevância. Ela deve nos acompanhar como um guia, ajudandonos, em cada passo, a evitar reificações, reducionismos, focos unilaterais e a absolutização empobrecedora. No entanto, ainda estamos muito longe do momento em que essa preocupação corresponderá a um risco concreto, tangível e imediato - o que, insisto, não deve ser motivo para a negligenciarmos. Hoje e, suponho, por muitos anos ainda, o problema me parece ser exatamente o contrário: a falta de reconhecimento, no campo das ciências 
sociais, da segurança pública como problemática específica. A despeito de se destacar, há décadas, entre as principais questões da agenda pública brasileira, a segurança ainda é tema desprezado e desconhecido, em nossa área. Um sintoma de que apenas merece atenção como objeto vicário e marginal, é o fato de que a bibliografia brasileira sobre o assunto é quase exclusivamente dedicada às causas da violência e da criminalidade - e, eventualmente, às consequiências de sua existência na magnitude em que a vivenciamos, nas principais metrópoles brasileiras, especialmente nos bairros populares e nas favelas. Nossos estudos são, praticamente todos, diagnósticos. Não me recordo de nenhum trabalho acadêmico, nas ciências sociais brasileiras (não me refiro aos campos do direito e afins), devotado ao exame de políticas públicas de segurança. Essa foi, inclusive, a principal motivação para que eu escrevesse Meu Casaco de General. Como nos acostumamos a pensar que o crime é um epifenômeno, uma consequiência ou um espelho de suas verdadeiras razões ou causas, jamais nos demos conta de que, independentemente dos vínculos de dependência entre o crime e as estruturas socio-econômico-culturais, aquilo que chamamos e que aflige a sociedade como criminalidade existe em modalidades peculiares e representa um problema dotado de relativa autonomia. Problema que, enquanto tal, exige procedimentos apropriados por parte do Estado e intervenções adequadas por parte da sociedade civil. Procedimentos e intervenções que podem produzir efeitos importantes. Nosso silêncio é grave e contribuiu para as dificuldades que os governos democráticos e progressistas freqüentemente demonstram para enfrentar o problema. Os ativistas dos direitos humanos, entre os quais me incluo, também custamos muito a reconhecer a insuficiência da postura exclusivamente crítica, denuncista, e a necessidade de completá-la com a defesa de propostas alternativas, realistas e eficazes. Discuto esse ponto no livro: nossa omissão e suas consequiências políticas. Por isso, polícia é ainda um tema considerado menor, quase abstruso: "coisa de baixo clero", na melhor das hipóteses, como diriam alguns de nossos mestres, torcendo os narizes, superiores. É absolutamente extraordinário que a reforma da polícia ainda seja uma questão estranha às nossas teses de mestrado e doutorado, e que políticas públicas de segurança, em perspectiva transnacional comparada, ainda seja um tópico inexistente em nossos principais currículos. E justamente no Brasil, cujos destinos democráticos talvez dependam (entre outras coisas) do que

Horizontes Antropológicos, Porto Alegre, ano 7, n. 15, p. 239-270, julho de 2001 
pudermos fazer nessa área. Por isso, são exceções notáveis os trabalhos de alguns poucos colegas, entre os quais Roberto Kant de Lima, Antônio Luiz Paixão, Paulo Sérgio Pinheiro, Sérgio Adorno, Marcos Bretas e Jacqueline Muniz (a listagem está longe de ser exaustiva, mas, mesmo assim, insisto: os nomes são realmente poucos). Espero que, nos próximos anos, esse espaço de pesquisa e reflexão, finalmente, se abra e conquiste a legitimidade que merece - recuperando a nobilidade que os clássicos lhe conferiam, desde Hobbes. Dialeticamente, pretendo dar minha contribuição para que criemos um novo quadro acadêmico, no qual, um dia, ganhe plausibilidade imediata sua preocupação com o risco de que exageremos no foco sobre a segurança. Prometo estar a seu lado, cerrando fileiras para criticar o exclusivismo, a reificação e a absolutização em que a temática, nesse momento futuro, correria o risco de degradar-se. De meu ponto de vista, perigoso, hoje, perigosíssimo, é o fato de que a maior parte dos cientistas sociais brasileiros ainda desconhece o significado, para as classes populares, do terror que lhe impõem a tirania do tráfico e o despotismo policial. Continuamos a pensar o Brasil pelo viés do estado de direito e das liberdades democráticas, como se o Estado democrático, seu aparato repressivo e a vigência formal das leis correspondessem a uma realidade civilizada de cidadania real. Não é verdade. Esse retrato otimista não vale para milhões de brasileiros, que vivem numa terra sem lei, submetidos ao arbítrio mais extremo. Para esses, o Estado é o policial uniformizado na esquina. A Polícia é o elo entre a forma e a substância, em nossa democracia. Enquanto nossos colegas não compreenderem a imensa gravidade desse quadro, a magnitude do sofrimento e a profundidade da exclusão, estaremos vivendo o pior perigo. Tomara que o perigo que você (e eu) teme(mos) chegue logo, porque, provavelmente, teremos avançado muito e estaremos em uma situação bem melhor.

\section{Gustavo Lins Ribeiro}

Gustavo: Você tem uma formação híbrida de cientista político e antropólogo. De que maneiras e com que intensidade elas se cruzaram na sua experiência na Secretaria? Quais aspectos negativos e quais positivos de cada disciplina dificultaram ou facilitaram sua capacidade de interpretação e sua atuação? 
Luiz Eduardo: Acho a pergunta muito interessante. Na verdade, ela seria matéria para uma longa reflexão, da qual poderia surgir um ensaio ou até um trabalho de mais fôlego. No entanto, nesse momento, não saberia o que dizer, porque as diferentes vertentes que formaram a (precária e por vezes contraditória) unidade que sou eu, como ator social, agente político, indivíduo, cidadão e subjetividade intelectual, plasmaram-se de tal forma para que o pronome eu se configurasse como sujeito, que somente uma análise (de múltipla procedência) as poderia distinguir, avaliando seus pesos relativos em mim e em meus atos. Sob o fogo cruzado das tensões e lutas cotidianas, no governo, o que se movimentava, pensava, discutia e agia era esse compósito heteróclito porém, em algum nível, íntegro/integrado. Talvez eu deva à antropologia meu interesse especial e os investimentos políticos que promovi pela causa das chamadas minorias estigmatizadas, assim como a atenção às questões de gênero e etnia. Talvez haja algo de antropológico na importância que dava à recomposição da imagem das instituições. Mas, certamente, o elemento mais destacadamente antropológico foram as considerações que inspiraram nosso método (meu e da equipe) de relacionamento com a mídia e o imaginário coletivo. Exploro um pouco esse ponto na resposta que ofereço à segunda pergunta de Rita Segato, muito semelhante a esta.

Gustavo: De que forma a sua trajetória militante de esquerda, desde sua juventude, influenciou a sua decisão de assumir um cargo tão sensível e de tanta responsabilidade? A partir desta trajetória e da experiência recente na Secretaria como você avalia o papel do intelectual crítico brasileiro hoje? $\mathrm{O}$ que poderíamos dizer, neste âmbito, aos jovens cientistas sociais que estão começando?

Luiz Eduardo: Sim, acho que nunca deixei de ser um membro de minha geração intelectual, pós-68, que cresceu na resistência à ditadura e que adotou um marxismo retemperado pela psicanálise e pelas críticas ao modelo soviético, ao estalinismo, aos dogmatismos, ao partido único, à ditadura do proletariado, ao autoritarismo tecno-burocrático. Sempre fomos libertários, sem sermos anarquistas; revolucionários, mas contrários à violência e aos autoritarismos salvacionistas; socialistas sem aceitarmos as restrições às liberdades individuais e à criatividade econômica; e 
internacionalistas, valorizando, entretanto, a diversidade local e as identidades nacionais. Além disso, também é típico de minha geração o engajamento cívico e político, em uma clave nada pós-moderna. Pelo contrário, bem modernista, segundo a qual as vanguardas são necessárias na política, nos processos de auto-invenção pessoal e nas artes.

Quanto à questão sobre o papel do intelectual, bem... ela é tão importante e tão difícil, que mereceria um ensaio, um livro, todo um seminário. Quero deixar claro, em primeiro lugar, antes de dizer qualquer coisa e deixar-me levar pelas paixões, que não pretendo generalizar as impressões e, muito menos, ser normativo. Sou um pluralista convicto. Acho que há ou deve haver espaço para todo tipo de produção, para todos os estilos de criação intelectual, na academia. Sempre fui e continuarei a ser um defensor radical desse pluralismo irredutível, até porque aquilo que, hoje, nos parece errado e insignificante, até contraproducente, pode abrir picadas para a gestação de novos métodos, novos conceitos e teorias, novas abordagens, cuja relevância só o futuro julgaria. Às vezes nós temos a sensação de que estamos mais perto da verdade ou dos objetos verdadeiramente importantes, porque estamos olhando para o sol. E não nos damos conta de que, assim, terminaremos cegos, incapazes de ver o que quer que seja, sobretudo os detalhes que fazem as diferenças. Essa profissão de fé pluralista não me impede, entretanto, de assumir meus próprios pontos de vista críticos e fazer meus julgamentos, com o propósito de me autocriticar, me corrigir e de redescobrir, a cada passo, qual deveria ser, para mim mesmo, o caminho a seguir, dados os meus valores. Portanto, insisto: o que eu escrever nas próximas frases expressa meu ponto de vista contingente, fruto de minha trajetória, de minhas experiências. Claro que eu gostaria que o máximo de colegas viesse a concordar comigo. Mas eu sei que muitos discordarão e acho isso realmente saudável, sem demagogia, exatamente para que o indispensável pluralismo conviva com o livre exercício da crítica.

Tendo dito isso, eis minha percepção: acho que a academia brasileira, na área das ciências sociais, está muito distante do Brasil e até mesmo do mundo. Nós não temos dedicado tempo suficiente para entender quais as necessidades específicas de nossos alunos, nos planos da formação e da realização profissional. Temos oscilado entre dois extremos: ou fingimos que não está acontecendo nada à nossa volta, que a sociedade brasileira não 
está gritando, uivando de dor, ao nosso lado, pela magnitude das injustiças, violências, opressões, e continuamos nos portando como se estivéssemos em Harvard, Oxford ou Heidelberg, ou dizemos que a grande tradição humanista é mero ecletismo generalista, simples irrelevância erudita, inadequada à era da informação, à fase atual do capitalismo transnacionalizado, e passamos a defender a adaptação da academia ao mercado. Ou seja, passamos a preparar rapazes e moças para apertar os botões nas oficinas globais do sistema neoliberal, harmonizado pelo "pensamento único". Tarefa ideológica (e de apoio econômico) primária de geração de força de trabalho funcionalmente adaptável. Isso é muito triste e me parece, de longe, pior que a solução cínica da torre de marfim elitista. A postura aristocrática pelo menos tende a abrir espaços e brechas crítico-reflexivas, além de representar um obstáculo deseconômico ao trator globalizantefuncionalizante-adaptativo. O que falta é a academia inteiramente engajada, apaixonadamente engajada na identificação de nossos problemas e na criação de soluções factíveis, sustentáveis, consistentes e eficazes. Não advogo a necessidade da participação dos intelectuais em governos, ONGs ou partidos, mas a necessidade de sua contribuição via concepção, análise e avaliação de políticas públicas ou de projetos aplicados. Entretanto, sonho com uma academia que viva essa imersão, que ultrapasse sua alienação experimentando total liberdade de escolha, de crítica, de posicionamento, de pesquisa, de estudo, mantendo, portanto, forte autonomia. Temos de ser sensíveis ao escândalo da fome, da humilhação, do sofrimento social extremo, da hipocrisia convertida em bom senso ilustrado. Temos de respirar a urgência da mudança. Sem esse acicate ético, continuaremos tocando nossas vidinhas de costas para o incêndio das cidades, assobiando para nos distrair dos rugidos da barbárie, preocupados com nossas "verbinhas", nossas ridículas "briguinhas" de departamento, nossos pequenos narcisismos, nossas grandes vaidades, nossas poses, nosso charme indiscreto. Por vezes, a economia autofágica dos micro-poderes departamentais nos leva a odiar colegas que sabemos serem íntegros, honestos, bem intencionados e, no fundo, parceiros da mesma luta - e nós não podemos mais nos dar ao luxo de desperdiçar energias com neuroses institucionais e de nos afastarmos dos que teriam tudo para cerrar fileiras conosco, frente às causas maiores. Nossas associações terminarão virando sindicatos corporativistas, obcecados por salários e greves, ou salões de chá para tertúlias elegantes 
(desdenhosas do baixo clero), meros clubes para as fofocas e os bizarros "joguinhos" dos micro-poderes. Na medida em que crescemos como comunidade, nossa produção se complexifica e enriquece. O efeito paradoxal é que isso parece nos liberar do compromisso profissional e ético-político de olhar para fora, para além do jardim. Mais e mais haverá bons temas de teses sobre nós mesmos, sobre o que dizemos e diremos, sobre o que disseram nossos mestres, etc. A auto-referência proverá alimento crescente para a reprodução ilimitada de nossa máquina de produção de bijuterias sofisticadas. Acho nossa paisagem acadêmica muito triste, apesar de povoada de gente brilhante, da maior competência e seriedade. Eu sou parte do cenário. Por favor, compreenda. Eu me vejo como parte do cenário, parte do problema, que ajudei a criar. Mas talvez nunca seja tarde para recomeçar.

Vou lhe dar um exemplo: um dia, cheguei da secretaria de segurança arrasado. Um adolescente tinha sido assassinado por policiais, a luta interna ao governo superava todos os limites, a guerra era jogada em todas as frentes, os telefones de minha casa não paravam, com ameaças e palavrões, e o governador me telefonara informando que o gabinete militar descobrira um complô para atentar contra minha vida e a de minha família, envolvendo um mapa detalhado dos deslocamentos rotineiros de minhas filhas. Era difícil dormir. Liguei o computador. Era uma hora da manhã. Entrei no email. Lá estava uma troca de insultos entre dois colegas, que brigavam e se agrediam intensamente, porque um achava que o outro não lhe prestara as homenagens devidas, pois o teria informado de modo inapropriado a respeito de certa oportunidade de pesquisa. Tive a certeza de que esses dois colegas, grandes figuras humanas, profissionais extraordinários, corações generosos, seres humanos honestíssimos, da maior dignidade e respeitabilidade, admirados por toda a comunidade, tive a certeza de que eles sofreriam, naquela noite, a mesma insônia que eu. E me dei conta do descalabro. Ora bolas, estamos todos do mesmo lado. O povo está sendo usurpado e humilhado por bandoleiros e saqueadores empoleirados no Estado. Grassam a corrupção, o oportunismo mais deslavado, a mais absoluta falta de vergonha. Enquanto isso, aqueles meus dois queridos amigos, generais do nosso exército, estavam se matando simbolicamente por nada. A "vidinha" de departamento auto-referida e o orgulho besta são piores que o alcoolismo e a drogadicção: fazem as pessoas, mesmo as melhores, perderem inteiramente o senso de medida e o rumo. 
Comentário (Luiz Eduardo, segunda rodada): Acho que está faltando fazermos uma discussão sobre intelectualidade e poder no Brasil, abrangendo tanto uma breve história das últimas décadas que deveria começar, ao menos, desde a resistência à ditadura e terminar com avaliações propositivas. Afinal nós estamos em um país cujo presidente da República é um sociólogo, por sinal um dos que fez a cabeça de várias gerações de cientistas sociais brasileiros e [foi?] o mais conhecido no exterior. É sintomático o embaraçoso silêncio que reina diante de tópico tão importante. Onde estão os trabalhos sobre "o CEBRAP no poder", para colocá-lo de maneira provocativa? Além disto, todos nos lembramos, os membros da geração pós-68 que você falou, de como nos engajamos consistente e corajosamente contra o arbítrio militar. Porém, de fato, retrospectivamente - parte em função da normalização e complexificação da vida acadêmica brasileira, parte frente ao desaparecimento do autoritarismo ditatorial, o óbvio inimigo comum - é visível o crescimento de um certo conservadorismo que parece (digo parece porque acho suscetível a discussão) consolidar-se nos anos 90, pós Constituinte. Não sei em que medida tudo isto reflete, também, uma relação mais sofisticada com o poder e o seu gerenciamento, e não meramente a exclusão como acontecia na ditadura. De qualquer forma, insisto na necessidade de refletirmos mais criticamente sobre a relação ciências sociais/poder no Brasil contemporâneo, em um sentido amplo que inclua o protagonismo de Fernando Henrique Cardoso, Ruth Cardoso, Vilmar Faria (para pensar no Palácio do Planalto hoje) e de muitos outros que, atuando no Estado ou fora dele (pessoas como você mesmo, como Rubem César Fernandes, Mary Allegretti, Alfredo Wagner, Aurélio Vianna e tantos outros que me escapam à memória), vêm se comprometendo com a vida pública e a política. Uma última palavra. Como você sabe, sou pelo engajamento direto que você preconiza. Acho, porém, e sei que você concorda comigo inclusive pelo cuidadoso preâmbulo "pluralista" que fez, que muito da contribuição que os cientistas sociais podem dar se situa no âmbito mesmo da sua profissão, na formação, através da pesquisa e da docência, de uma consciência social e política crítica. Não falo isto para apaziguar nossas ansiedades nem para relativizar a necessária sensibilidade para com uma prática sintonizada com o destino dos excluídos e vitimados da desigualdade no país. Falo isto porque acredito também na luta por hegemonia ideológica onde, creio, na maior parte do tempo estamos situados.

Horizontes Antropológicos, Porto Alegre, ano 7, n. 15, p. 239-270, julho de 2001 
Gustavo: Você não considera que em determinados episódios reagiu de forma impulsiva ou voluntarista? Penso, ao menos, nas "cenas da Mangueira", onde você aparece no meio dos distúrbios, helicópteros com homens armados, etc., e no conflito que acabou determinando sua saída do governo.

Luiz Eduardo: No caso da Mangueira, a resposta é não. E não tenho dúvida nenhuma quanto à correção da resposta. Minha intervenção evitou um confronto de conseqüências imprevisíveis. A comunidade voltou para a favela e os policiais retornaram aos Batalhões. O capítulo sete ("Fala, Mangueira") de meu livro é dedicado ao episódio. Não houve ali nenhum voluntarismo, mas a resposta rápida e não-convencional a uma emergência. Negociei com a comunidade. O que ela desejava? Apenas que se fizesse justiça e que os policiais que assassinaram um menino, naquela manhã de maio de 1999, fossem punidos, para que aquele tipo de tragédia não se repetisse. E isso exigiria que os depoimentos das testemunhas fossem colhidos em segurança. Freqüentemente, os policiais que matam escapam da Justiça, seja porque a corporação os protege, seja porque as testemunhas temem delatá-los. Prometi à comunidade condições especiais de segurança para que os depoimentos fossem prestados e cumpri a palavra. A comunidade acreditou em mim e recuou, abandonou a rua que ocupara e aceitou jogar o jogo dos procedimentos legais. O helicóptero a que você se refere surgiu inesperadamente, como uma provocação de determinados setores da Polícia, quando a situação já estava sob controle. Quase pôs tudo a perder, mas eu fui firme, determinei na hora, pelo celular, a punição dos policiais e o imediato afastamento do helicóptero. As negociações foram então retomadas e conduzidas a bom termo. Minha intervenção estabeleceu um novo padrão de relacionamento - mais respeitoso e com mais confiança mútua - entre as autoridades da segurança e as comunidades das favelas. Por outro lado, impôs um recuo aos setores da Polícia que lutavam pela desestabilização da nova política de segurança e que duvidavam de minha disposição de confrontá-los. Durante os 15 meses em que estive no governo, houve bem menos protestos violentos contra a Polícia do que ocorria antes e do que voltaria a ocorrer depois. O motivo é simples: reduzimos em $35 \%$ os homicídios praticados por policiais e restringimos drasticamente as práticas violentas. Instituímos a Ouvidoria da Polícia, que Julita Lemgruber dirigiu, e estivemos presentes, quotidianamente, ouvindo, dialogando com 
as comunidades e valorizando suas organizações. Como os moradores, não só as lideranças, tinham o número de meu celular, era mais fácil acordarme e contar-me o que estava acontecendo, de madrugada, do que descer a favela e incendiar ônibus para exigir Justiça. Todos sabiam que eu agiria com presteza e que não admitia os velhos métodos. Estávamos construindo uma bela aliança entre as comunidades e o governo, baseada na idéia de respeito à lei. Isso que parece simples e bastante conservador, respeito à lei, é, na verdade, revolucionário na periferia e nas favelas do Rio. Mas não quero iludir ninguém. Ainda havia muita violência policial, muita corrupção e muito crime. Estávamos muito longe do mínimo aceitável.

Quanto à segunda parte da pergunta, sobre o conflito que causou minha exoneração do governo, é difícil responder. Já a discuti em resposta a uma pergunta do João Trajano, mas acho que poderia aproveitar para acrescentar outras observações. Estava envolvido no processo e não tenho ainda a distância necessária para uma reflexão crítica razoavelmente isenta. O que lhe posso dizer, hoje, é que não creio que tenha agido voluntaristicamente. As razões me levaram a escrever algumas centenas de páginas. Meu Casaco de General, além de ser uma apresentação da política de segurança que começamos a implementar, eu e a equipe que trabalhava comigo, é também um relato sobre o dia a dia nos bastidores do governo e, por conseqüência, é também uma narrativa dos motivos que me levaram a fazer o que fiz. Eu acreditava que, depois de vários meses tentando dissuadir o governador a adotar a estratégia que escolheu, desde que nomeou o segundo chefe de Polícia Civil, em 13 de dezembro de 1999, não me restava outro caminho. Eu esgotara todos os meios, todos os recursos. Todas as minhas tentativas se frustraram. Pior: na medida em que ficava claro que eu não admitiria o tipo de aliança em vigor (por razões éticomorais e até mesmo práticas, porque elas nunca funcionaram, sempre concorreram para aprofundar a degradação institucional), passei a perder poder. Foi ficando claro que eu passaria a funcionar como legitimador de um caminho que deixara de corresponder à política que, com o apoio do governador, comprometemo-nos com a sociedade a implementar. Observadores mais atentos do quadro, como os jornalistas Élio Gaspari a Arnaldo César, já haviam detectado e escrito sobre o impasse que eu vivia, sob tensão e pressão crescente. Precisei aproveitar uma situação que surgiu independentemente de minha vontade, para criar um quadro em que o

Horizontes Antropológicos, Porto Alegre, ano 7, n. 15, p. 239-270, julho de 2001 
governador teria de decidir se desejava manter-me ou se preferia seguir o rumo que vinha privilegiando, já que, até aquele momento, ele não abandonava a ambigüidade, a qual aliás lhe servia muito bem, pois permitia dizer à sociedade que continuava empenhado em operar as mudanças prometidas (e minha presença o atestaria), restabelecendo, todavia, as velhas alianças dos governos conservadores, na equivocada suposição de que, cooptando a "banda podre", a subordinaria. É preciso ter em mente que, no campo da segurança pública minado pelo crime, não se faz política no sentido usual, pois o segmento mais significativo dos adversários não segue as regras da institucionalidade vigente, não obedece nem mesmo o código penal: mata, tortura, chantageia, ameaça, seqüestra, extorque, promove atos terroristas, sabota as iniciativas do governo. Portanto, a virtude não está em ser tolerante, flexível, plural e amplo. Ao contrário de outros setores da vida pública, na segurança é preciso ser inflexível, intolerante e radical com os criminosos fardados, nos limites da lei e das regras institucionais. Ou nós continuaremos afundando cada vez mais na barbárie. Isso não quer dizer que não devamos buscar alianças amplas, no interior das polícias.

Gustavo: Como foi, para você, um pacifista, conviver com um cotidiano de armas, violência, prepotência e dor?

Luiz Eduardo: Deve ser algo parecido com a experiência do médico, obrigado a conviver com a dor e a morte, apesar de vocacionado para promover a vida e a saúde. Sei que os médicos, para sobreviver, acabam criando uma espécie de defesa, de proteção psicológica, para reduzir sua exposição às emoções dos pacientes e de suas famílias. Eu não tive tempo de chegar a esse estágio de adaptação. Por isso, cada tragédia continuava a ser muito mobilizante. Mas o resultado foi o reforço, em mim, das convicções pacifistas.

Gustavo: Você, hoje, goza de uma grande visibilidade política no Rio de Janeiro, visibilidade que tem duas faces. A positiva leva a crer na possibilidade de uma carreira política. Você está considerando esta possibilidade? A negativa implica em um problema de segurança pessoal e familiar. Como você avalia o impacto de sua luta política na sua carreira acadêmica e na sua vida em geral? 
Luiz Eduardo: Gostaria, sim, de ter a possibilidade de continuar a implantação dos projetos que comecei a implementar. Quanto à segurança pessoal e familiar, sei que ainda há motivos para preocupações, mas, nesse caso, a visibilidade mais ajuda que atrapalha. Ela foi e continua sendo um escudo protetor. Quanto ao impacto do envolvimento político sobre a carreira acadêmica e a vida, é imenso. Pode vir a se revelar devastador ou enriquecedor, dependendo do que eu seja capaz de fazer com a experiência acumulada. Devo confessar, por exemplo, já que estamos aqui entre colegas (os leitores e os autores dessas perguntas), que o livro que escrevi ao longo do ano 2000 (citado acima) é um esforço de gerar as condições de uma articulação enriquecedora entre a experiência e a reflexão. Se me é permitida uma observação sobre o livro, ousaria afirmar que só na aparência a reflexão está ausente em benefício da narrativa subjetivo-etnográfica e da descrição de nossa política de segurança, com seus projetos e programas. É possível interpretar o livro não como uma ruptura em minha produção, mas como um passo natural, numa seqüência contínua. Eu redigi, em 1997 e 1998, ensaios para duas coletâneas (uma organizada por George Marcus, Paranoid Reason, e outra por Scott Lash, Time and Value), nos quais desenvolvi uma abordagem narrativo-etnográfica, de corte assumidamente subjetivo/confessional e reflexivo, cuja primeira versão apareceu no texto de 1994, "O Herói Serial", que fechava meu livro (com colaboradores), Violência e política no Rio de Janeiro (Relume Dumará, 1996). Lembro também que publiquei um romance, em 1997, tematizando violência, polícia, crime e política ( $O$ Experimento de Avelar; Relume Dumará). Os experimentos com a narrativa etnográfica, suas vinculações com a questão do sujeito, da linguagem e da política, têm sido uma constante para mim, portanto, desde pelo menos 1994 - isso se deixarmos de lado exercícios esparsos, como o artigo "Misticismo e Reflexão", publicado em meu livro $O$ Rigor da Indisciplina. Pensando o problema pela perspectiva da continuidade intelectual ou acadêmica, é interessante registrar que em julho de 1998, organizei um seminário internacional para inaugurar o novo doutorado multidisciplinar que criamos no Departamento de Ciências Sociais da UERJ. Convidei George Marcus, entre outros antropólogos, e combinei com ele que escreveria uma etnografia do poder, possivelmente para ser publicada na coleção que ele dirige, focalizando a área da segurança pública. Eu recorreria às facilidades que derivariam de minhas liga-

Horizontes Antropológicos, Porto Alegre, ano 7, n. 15, p. 239-270, julho de 2001 
ções com Garotinho, caso ele vencesse as eleições para o governo do estado, em fins de 1998. Pensei em entrevistar o novo governador e as autoridades da área, ao longo do primeiro ano de mandato, e observar o que pudesse, obtendo licença para assistir reuniões, etc. Esse era meu plano acadêmico, intelectual, quando nem de longe poderia imaginar que viria a produzir, um dia, a tal etnografia através do método da "observação participante"... Era meu plano acadêmico porque correspondia à convergência de minhas duas formações, a antropológica e a política. Às vezes achava a antropologia muito despolitizada e, freqüentemente, considerava nossa ciência política excessivamente positivista e insensível para as dimensões decisivas da intersubjetividade. Por isso, por um certo ângulo, poder-se-ia dizer que o que se cumpriu, na verdade, bem ou mal, mas com coerência e radicalidade, foi um projeto intelectual. Nesse sentido, não teria havido interrupção ou ruptura.

Gustavo: Depois de ter estado em um dos cargos públicos mais problemáticos do Brasil, quais as principais lições que você aprendeu em termos do que deveria ser uma política de segurança para o Rio de Janeiro e para outras cidades do país? A segurança tem jeito no Brasil? Como combater a violência (de ambos os lados) e a corrupção?

Luiz Eduardo: Aprendi que faz muita falta a reflexão acadêmica sobre políticas públicas de segurança. Temos muitos interessantes estudos sobre a violência, mas nenhum trabalho de peso sobre políticas para enfrentar a questão. Aprendi que o nó mais grave de nosso imbróglio, na segurança, é gerencial. Concluí, com base na experiência, que precisamos de modernização gerencial e tecnológica (o que implica capacitação dos profissionais), moralização (com mudanças institucionais e controle externo, além de indução positiva) e participação comunitária. Mas a pré-condição para os avanços é a qualificação dos dados, sem cuja consistência e distribuição racional não há diagnóstico, sem o qual não há planejamento, na ausência do qual não há avaliação, monitoramento e correções sucessivas, isto é, aprendizado com os erros. A qualificação dos dados, a consistência das informações, por sua vez, dependem da credibilidade das instituições policiais, que não se alcançará sem moralização e participação social. Por isso, em síntese, a eficiência será função da credibilidade, da confiança, as quais serão decorrência do respeito com que os policiais trataremos os 
cidadãos, indistintamente. Complementarmente, a credibilidade policial também derivará da eficiência de seus serviços. Portanto, eficiência e respeito aos direitos humanos são indissociáveis e mutuamente indispensáveis. Em resumo: creio que poderemos melhorar muito a qualidade dos serviços policiais e que isso seria extremamente importante, até mesmo para melhorar a vida dos mais pobres, sujeitos, freqüentemente, à tirania de criminosos (policiais e não-policiais). Mas isso nem de longe significaria a resolução do problema da segurança no Brasil. A "solução", tanto quanto se possa usar essa palavra sem ingenuidade, isto é, a produção de uma ordem razoavelmente pacífica e de uma sociabilidade razoavelmente cooperativa, entendida como modelo ou tipo ideal, só poderia aproximar-se de nossa realidade se houvesse mudanças profundas em nossas estruturas socioeconômicas, reconhecida e ostensivamente injustas.

Gustavo: Você pretende voltar a viver no Brasil?

Luiz Eduardo: Sem dúvida. Gostaria de voltar em breve para o Brasil, mesmo que seja conveniente adiar um pouco o retorno ao Rio de Janeiro (depois de escrever esta lacônica resposta, recebi e aceitei um honroso convite do prefeito Tarso Genro para desenhar um projeto de segurança cidadã para o Município de Porto Alegre. Portanto, a fortuna me levará (me trouxe) para a cidade em que vivem os editores desses Horizontes Antropológicos, o que faz desta entrevista uma inesperada antecipação fraternal desse encontro).

\section{Rita Laura Segato}

Rita: Como você responderia à crítica de alguns acadêmicos (expressa, por exemplo, entre outros, no programa Roda Viva, pelo Prof. Paulo Sérgio Pinheiro) de que não seria adequado ultrapassar os muros do claustro universitário e combinar a produção de conhecimento com a participação na administração, a posição de quem sugere soluções com a de quem executa medidas?

Luiz Eduardo: Compreendo e respeito o cuidado do Prof. Paulo Sérgio Pinheiro, que, de resto, além de importante referência intelectual e ética em nosso campo profissional, tem sido um colega solidário nos momentos mais difíceis. Acho que ele quer dizer que a função intelectual deve ser, em 
alguma medida, sempre polêmica e crítica, ou seja, precisa de autonomia, de independência, como seu alimento essencial. No entanto, eu discordaria da generalização desse postulado, se é que ele a propôs, uma vez que, para mim, a função intelectual deve manter também um compromisso pragmático permanente com as possibilidades de transformação inscritas na realidade histórica. E nada melhor para conhecer e intervir sobre essas potencialidades do que a vida pública, sobretudo no executivo, onde também se aprende a respeitar os limites ditados pelas circunstâncias. O importante, creio, é manter a vitalidade dessa dupla perspectiva, a crítica que provém do olhar autônomo e o compromisso pragmático oriundo da imersão nas condições do real histórico. Mesmo que essa vitalidade ambivalente e tensa exija uma divisão do trabalho, em que cada um de nós ocupará posições provisórias e intercambiáveis. E mesmo que ela gere tensão entre nós e dentro de nós, porque também nós, com nossa infatigável consciência autocrítica (não é essa a boa doença irremediável que faz de alguém um intelectual, no sentido pleno do termo?), somos arenas dessa duplicidade de perspectivas e posturas. Exemplifico: consideremos dois personagens extremos. Veremos que a ambos falta uma parte fundamental. Um deles é o crítico sectário, o visionário romântico, ótimo na crítica mas inteiramente ignorante das condições concretas em que mudanças se viabilizam, politicamente. Esse é o insensato, geralmente arrogante e autoritário, que acaba substituindo a reflexão pela paixão, no sentido solipsista e, portanto, narcísico do termo. O ressentimento abúlico é seu destino final. O outro personagem é o realista capitulacionista, cujo discurso crítico mal esconde a exaltação conservadora dos limites, que só acredita em "processos complexos de longo prazo" e chama os outros de jacobinos totalitários. Esse personagem acaba se rendendo a uma posição autoritária e arrogante, tecnocrata e positivista, em que a idealização da razão ocupa os espaços abandonados pela paixão e pela vontade. $\mathrm{O}$ conformismo e a racionalização auto-indulgente constituem seu destino final. Acredito que nossa meta deve ser a busca incessante do antídoto contra a identificação unilateral com um desses dois personagens polares. E essa busca pode se dar dentro e fora das universidades, dentro e fora dos governos.

Rita: Você identifica alguma especificidade na maneira em que você, por ser antropólogo, realizou essa passagem do claustro universitário para o poder? 
Luiz Eduardo: Acho que sim. Não sei em que medida devo à antropologia, à psicanálise ou a algumas idiossincrasias pessoais a atenção obsessiva aos aspectos simbólicos e afetivos envolvidos na construção coletiva e intersubjetiva da segurança, como um bem público. O modo como eu e minha equipe nos relacionamos com a mídia foi bastante original, concorde-se ou discorde-se dele. E esse modo tinha a ver com a referida atenção ao simbólico, ao afetivo e ao imaginário coletivo. Discuto bastante esse ponto no livro, Meu Casaco de General.

Rita: Você acha que existe algum tipo de idéia ou sugestão de medida a ser tomada que somente um antropólogo, a partir do seu treinamento, seria capaz de imaginar para a área da segurança pública, tornando a sua contribuição idiossincrática e diferente da de outros cientistas sociais?

Luiz Eduardo: Não sei. O contrafactual é sempre um risco especulativo. Os projetos e programas que compuseram nossa política não foram imaginados por mim, individualmente, mas por uma equipe interdisciplinar. Acho que tive o mérito de apostar na multidisciplinaridade e na escolha de profissionais de alto nível, muito sensíveis e criativos. Beneficiei-me da ótima escolha que fiz. Eu me orgulho de saber trabalhar em equipe. Além do mais, felizmente, o trabalho coletivo me dá um enorme prazer. Acho que a marca de nossa política é sua origem multidisciplinar. Nossos grupos de trabalho envolveram antropólogos, sociólogos, economistas, especialistas em informática, engenheiros de diferentes qualificações, policiais, psicólogos, assistentes sociais, cientistas políticos, historiadores, geógrafos, urbanistas, arquitetos, administradores, advogados e membros das comunidades envolvidas. Nossas equipes costumavam ter mais mulheres do que homens. As idades variavam muito. As cores de pele, identidades étnicas e sexuais também.

\section{Hélio Silva}

Hélio: A política de segurança pública - nos parece à distância - foi central na eleição do Garotinho e você, sua equipe e o livro que editaram ainda em campanha corporificavam e materializavam a idéia. Se isto é correto, supõe-se por óbvio que a sociedade tinha nesse projeto uma prioridade notável. Já no Governo, você teve uma série de atitudes e ocupou 
a mídia num registro incomum, acenando para a possibilidade de providências originais e radicais em relação à forma como tradicionalmente a questão foi sempre tratada. Não obstante, se teve repercussões nacionais, sua saída parece não ter suscitado uma mobilização mais expressiva sobre o Governo, no sentido de honrar seus compromissos de campanha. Como você vê as organizações da sociedade civil no Rio de Janeiro em face dessa possibilidade de pressão e afirmação de suas aspirações?

Luiz Eduardo: Também me faço essa pergunta mas ainda não encontrei uma resposta que me satisfaça. O que sei é que a sensibilidade para um problema e a postura crítica não se convertem, naturalmente, em mobilização. Há muitas mediações, entre as quais o vínculo entre consciência crítica e organização, e entre ambos e a identificação de metas desejáveis e alcançáveis, capazes de indicar métodos de ação e um caminho para a prática. Por isso, só posso dizer que a reação da opinião pública à minha exoneração, que talvez tenha existido, provavelmente foi limitada, parcial, pulverizada e não se conectou com mecanismos organizacionais e metas claras. As manifestações foram localizadas: abaixo-assinados, indignação de muitos formadores de opinião, desagrado em comunidades que viviam ou acompanhavam de perto nosso trabalho. O PT criticou a medida do governo e, pouco depois, na seqüência dos acontecimentos, rompeu a aliança com o governador. No Rio, o PT estava enfraquecido e muito dividido, ainda que todos os segmentos tenham manifestado solidariedade a mim. Mas a falta de resposta mais concreta talvez tenha a ver, predominantemente, com quatro fatores decisivos: (1) eu não era membro de nenhum partido e minha nomeação havia sido uma escolha pessoal do governador, o que lhe dava liberdade de dispor de meu cargo com um grau de arbítrio pessoal maior do que ocorreria, se eu tivesse sido indicado por algum partido ou representasse alguma força organizada; (2) não há precedente de mobilização em defesa de um auxiliar não-partidário do governo. Além disso, faz parte das atribuições de um governador nomear e exonerar seus auxiliares. Por isso, só faria sentido uma mobilização contrária à minha exoneração se seu alvo fosse a defesa de uma política que porventura estivesse ameaçada por minha saída. Mas, nesse caso, a energia da crítica teria sido em parte esvaziada pelas promessas reiteradas do governador, segundo as quais a política que eu formulara e liderava seria respeitada e preservada. Acrescente-se a isso o fato de que a sociedade via com simpa- 
tia nossa política e se mostrava relativamente esperançosa de que ela pudesse vir a ser bem sucedida, mas essa simpatia e essa esperança ainda estavam muito distantes de uma persuasão plena e, mais ainda, de um entusiasmo capaz de despertar mobilizações. Um dos méritos que eu e minha equipe talvez tenhamos tido foi o de ajudar a reverter as expectativas tradicionalmente negativas sobre o futuro da segurança pública, fazendo-o de forma não-demagógica e não-convencional, isto é, sem repetir os velhos bordões "repressivistas". No entanto, mesmo sendo significativo, isso era muito pouco para provocar mobilizações em nossa defesa; (3) o setor do PT ao qual eu estava mais ligado foi aquele que, mesmo endossando o rompimento da coalizão governamental, ainda apostava numa recomposição com o governador, por ocasião das eleições municipais. A própria vice-governadora, Benedita da Silva, do PT, que havia sido uma aliada fundamental e permanente, enquanto estive no governo, viu-se diante de uma situação bastante delicada, pois me apoiava mas, por outro lado, contava com o apoio eleitoral do governador e não desejava colocar em risco esse apoio, tornando público um posicionamento crítico mais firme, no episódio de minha demissão e em seus desdobramentos. Aliás, essa postura acabou se revelando um equívoco, pois o governador não apoiou Benedita - de meu ponto de vista, jamais tencionou fazê-lo. A constante ambivalência a que a vice-governadora se condenou só a fez perder em todos os fronts. Meu caso foi apenas um exemplo. (4) Algumas das mais poderosas organizações da sociedade civil (esse, pelo menos, foi o caso do Viva Rio, com o qual tenho relações antigas e profundas) viram-se diante de um dilema: estavam a meu lado, mas compreendiam que o governador teria mais três anos de mandato. Seja do ponto de vista político, seja do ponto de vista estritamente pragmático, romper com o governo equivaleria a fechar as portas para uma cooperação que vinha sendo intensa e promissora, e cujos efeitos concretos já eram sensíveis; corresponderia a sinalizar para a sociedade uma posição negativa e fortemente pessimista. No entanto, apesar da ausência de mobilização, acho que algo ficou. Uma mensagem sobre os rumos que o governo do estado do Rio estava adotando foi captada pela sociedade e talvez produza resultados, quando combinada a outros fatores. Deve-se levar em conta o fato de que o governo navegava em águas políticas tranqüilas, quando fui exonerado, em março de 2000: tinha mais de $80 \%$ de aprovação popular, o governador já falava sem pudor 
em candidatar-se à presidência e não havia oposição ao governo, salvo na esquerda do PT e em núcleos, à época, isolados. Segundo o depoimento de deputados estaduais amigos meus, eu fui o membro do governo mais criticado pelos representantes da direita (na intensidade e na quantidade de pronunciamentos), na Assembléia. Havia resistência feroz à nossa política de segurança. Mas o governo, em seu conjunto, e o governador, em particular, não era criticado e vinha obtendo todas as vitórias que desejava, na Assembléia. Hoje, há oposição de todos os lados, o governador foi derrotado, eleitoralmente, na Baixada Fluminense, em Niterói, em São Gonçalo e na capital, áreas que concentram $70 \%$ do eleitorado fluminense. Ou seja, hoje, o que está em questão, para o governador, não é "perder" a presidência da República, mas suas chances de reeleger-se. Claro que o episódio de que participei não provocou esses resultados, mas creio que colaborou para a quebra daquele quadro idílico, a que se seguiu uma verdadeira derrocada. Ficou muito claro para mim que popularidade não significa, necessariamente, credibilidade. Talvez aquele episódio tenha produzido algum efeito nessa esfera mais delicada, a credibilidade do governo, para cuja produção concorrem os agentes mediadores, aqueles que denominamos "formadores de opinião", e que desempenham um papel peculiar, no Rio (papel que, por si só, mereceria um estudo).

Hélio: A questão particular da polícia no Rio de Janeiro pode ser enfrentada pelas vias tradicionais do "realismo" político nacional?

Luiz Eduardo: Não. Nossa velha tendência conciliadora não funciona em muitas áreas, ainda que eventualmente possa ser construtiva em determinados níveis e em circunstâncias específicas. $\mathrm{Na}$ área da segurança pública, certamente, não funciona, como se pode deduzir do exame da história recente. Refiro-me aqui, indiretamente, à minha resposta ao João Trajano, relativa à existência de três segmentos na polícia: há os líderes dos processos de mudança, há os policiais ambivalentes e limítrofes, mas cooptáveis por uma política decente, os quais devemos integrar aos projetos de reforma, mas há também os policiais criminosos. Esses devem ser combatidos. Conforme já disse, acho um equívoco a suposição de que a cooptação dos policiais criminosos promoveria sua subordinação à política do governo e permitiria controlá-los. Pelo contrário, com o tempo, são eles que se põem no controle e, de todo modo, arranjam sempre um jeito de, feitos aliados, 
garantir sua autonomia para, digamos, agir. Alianças com os adversários, nesse caso, termina por degradar-se em cumplicidade escusa. É preciso uma boa dose de jacobinismo, nessa matéria. Afinal, a democracia, no sentido que lhe confere a sociedade, não corresponde, necessariamente, às conveniências de corporações específicas. Ser democrático e agir democraticamente não significa deter-se ante cada ameaça de insurreição corporativista, sobretudo quando o que está em jogo não são propriamente interesses da corporação, mas outros, que prosperam à sombra do guardachuva corporativo.

Hélio: Em sua avaliação qual o saldo de sua passagem e de sua equipe pelo Governo, no sentido de conquistas irreversíveis ou de esforços desperdiçados (com o abrupto desligamento, é claro)?

Luiz Eduardo: É cedo para saber. Alguns projetos talvez deixem marcas, como as delegacias legais (redefinição de rotinas e funções, informatização, fim das carceragens, revalorização do espaço, ganhos salariais, etc.), a Ouvidoria, o disque-defesa-homossexual, as políticas de defesa das mulheres e das minorias, os mutirões pela paz, a focalização estratégica das armas, os projetos de requalificação profissional, em parceria com as universidades, as áreas integradas de segurança (nosso CompStat tropical), a reforma da polícia técnica, o Instituto de Segurança (meio de separar o joio do trigo, integrando - não unificando - as polícias), os conselhos comunitários de segurança, a introdução do planejamento com avaliações corretivas e dos diagnósticos com base em dados automatizados. Talvez fique algo da nova postura na comunicação (nas relações com o público e a mídia), transparente, que não esconde os erros, não é defensiva, não procura explicar tragédias, não justifica com linguagem técnica a morte e o sofrimento, e, por outro lado, encontra o timing apropriado para a difusão de um agenda positiva, diversa e sensível a tópicos específicos, mas integrada pela unidade orgânica de uma política. Talvez algo disso tudo fique, sob a forma de uma vaga esperança de que seja possível compatibilizar respeito aos direitos humanos com o investimento na eficiência policial. Por outro lado, o que se perdeu, o que perdemos foi tudo isso. É cedo para avaliar com exatidão. De todo modo, acho indiscutível que logramos introduzir a segurança pública, pela primeira vez, na pauta das esquerdas. 
Hélio: Qual seria sua proposta - hoje - para um modelo de polícia condizente com a realidade carioca e fluminense?

Luiz Eduardo: A PM teria de pagar decentemente e cobrar com rigor. Deveria reduzir a quantidade de patentes; modernizar seu regimento disciplinar, que é draconiano com as faltas administrativas e tolerante com o mau comportamento externo aos quartéis; operar uma descentralização que responsabilizasse e valorizasse as praças, na ponta, via difusão do modelo de policiamento comunitário. Deveria oferecer a oportunidade a todas as praças de ingressar nos cursos de oficiais, independentemente de casamento e idade. Deveria abrir-se corajosamente para as mulheres, adotando uma política de recrutamento dirigida para as mulheres. Deveria investir na formação e requalificação de seus quadros. Teria de redefinir prioridades e metodologias, táticas e estratégias, sobretudo no enfrentamento do tráfico de armas e drogas, desviando o foco do varejo das favelas para o atacado. Deveria desmontar sua corregedoria e criar mecanismos eficazes de controle interno (como a filmagem das operações), articulados à ouvidoria e a mecanismos de indução positiva. Teria de articular-se com a investigação da polícia civil, no planejamento operacional cotidiano, para superar a estupidez suicida e genocida das invasões bélicas de favelas. Deveria recuperar programas que a estreiteza dos secretários de segurança, desde 1995, suspendeu e exportou para São Paulo, como aquele destinado a oferecer acompanhamento psicológico aos policiais envolvidos em confrontos armados. Teria de abrir-se à sociedade e jogar todas as fichas na recuperação da credibilidade. Seria imperioso revolucionar o sistema de gerenciamento, armando a estrutura: qualificação de dados, análise e diagnóstico, planejamento, avaliação e monitoramento. Deveria impedir operações sem equipamento de comunicação adequado, que é tão importante quanto o armamento (ou mais, como ensinam os ingleses). Batalhões deveriam ser criados dentro das favelas, como unidades de serviços, formação profissionalizante, emprego e renda, tornando indistingüíveis políticas sociais e de segurança.

Já a polícia civil tem de começar de novo. Tem de ser recriada. Os instrumentos já existem. São os programas Delegacia Legal e CUPTEC (Centro Unificado de Polícia Técnico-Científica), cujo título nós tardiamente aceitamos mudar para POLTEC. A requalificação tem de ser total e 
radical, e um processo de resseleção tem de refundar a instituição. Nos limites permitidos pela Constituição, ambas as polícias devem integrar-se.

Hélio: Hoje, do exílio a que você e sua família estão submetidos, fruto por excelência de nossa impotência cidadã, como você avalia as possibilidades de mudança na esfera em que você atuou? E como você avalia sua atuação, suas alianças e os tropeços, ciladas e imprevistos que devem ter marcado o seu cotidiano no Governo?

Luiz Eduardo: Hélio, acho que já respondi a essa importante e sintética questão, ainda que de forma dispersa, em várias das respostas anteriores. Não faria sentido repetir.

\section{Ruben Oliven}

Ruben: A violência no Rio de Janeiro é um fenômeno endêmico ou é algo que tem solução?

Luiz Eduardo: Estamos condenados ao otimismo, para que o realismo indispensável a toda intervenção conseqüente seja ativo/criativo e não conformista, reativo/adaptativo. Um dos componentes fundamentais dos processos de mudança é a crença em sua possibilidade. Portanto, sua pergunta não pode receber uma resposta objetiva, até porque acho que, a rigor, ninguém a tem. A resposta será, forçosamente, parte do enquadramento e do enfrentamento do desafio. Daí minha afirmação de que, nesse caso, nossa alternativa é: esperança ou barbárie. Em outras palavras: meu caro mestre e amigo Ruben, é melhor pensar que sim, a violência no Rio é algo que tem solução.

Ruben: Se você pudesse fazer o tempo voltar, o que você faria diferente em sua atuação na Secretaria da Segurança?

Luiz Eduardo: Essa é a grande questão, porque é dela que se extrai o essencial do aprendizado proporcionado pela experiência refletida. Houve muitos erros, é claro. Os que vejo, hoje, e tantos outros que talvez ainda me escapem. O principal erro foi confiar no governador. Estavam certos os setores do PT que combatiam a aliança, em 1998, ainda que, em abstrato, a concepção que recomendava a aliança estivesse correta. Todos os demais 
erros que hoje reconheço são, direta ou indiretamente, consequiências deste. E não no sentido trivial de que só pude atuar no governo e, portanto, acertar e errar, porque confiei no então candidato, fiz sua campanha, seu programa e tornei-me seu subsecretário e depois coordenador setorial. Refiro-me à importância determinante do primeiro erro em outro sentido. Para ser bem específico: como a volubilidade do governador era enorme, em decorrência do estilo voluntarista com que processava a própria ansiedade, e como seu compromisso com o programa de governo que constituía nossa política de segurança era inteiramente superficial, oportunista, instrumental e politiqueiro/marqueteiro, eu gastei a maior parte de minhas energias evitando os estragos que seriam provocados pelos impulsos erráticos do governador, por seus destemperos verbais, suas idéias momentâneas, suas decisões precipitadas, inconsistentes e, muitas vezes, logo esquecidas. Para evitar esses estragos tinha de me antecipar, reduzindo as chances de que ocorressem. Para fazê-lo, dedicava muito tempo na persuasão cotidiana do governador e muito esforço para que os projetos ganhassem vida própria rapidamente, antes que fossem abortados ou destruídos no nascedouro por contra-ordens, opiniões contraditórias, novidades que os humores do dia ou os pesadelos da noite anterior inspirassem. A única forma de defender nossa política era colocá-la em prática e torná-la real, visível, socialmente reconhecida e aprovada, antes que desse na telha de Garotinho inventar uma idéia qualquer incompatível com nossos programas e com a seqüência lógica de sua implantação. Isso me levou a colocar na rua vários projetos ainda insuficientemente amadurecidos e insuficientemente negociados com as polícias, o que reduziu sua qualidade, suas chances de êxito e desgastou minha liderança junto às corporações. Os policiais, com freqüência e com razão, sentiram-se atropelados. Mas era uma questão de vida ou morte para nossa política. Se eu hesitasse ou decidisse seguir o caminho e o ritmo corretos, não restaria pedra sobre pedra, ante o tiroteio verbal de Garotinho e o festival de ordens aleatórias, desencontradas e, muitas vezes, inteiramente desafinadas com nossos projetos e seu eixo conceitual. Claro que eu não aceitaria trabalhar nessas condições, que acabaram virando um verdadeiro inferno, se tivesse adivinhado que Garotinho agiria com esse grau de inconseqüência. É como se um deus mitológico eólico soprasse os navios em que navegávamos quando bem lhe conviesse, para divertir-se com o desespero dos humanos. Se eu contasse com o apoio sólido e estável 
de um governador não-ciclotímico, menos voluntarista, menos desorganizador, improvisador e errático, poderia operar em outro ritmo, investir no amadurecimento gradual de cada projeto e negociar amplamente com os setores policiais com os quais se pudesse e devesse negociar. $\mathrm{O}$ jacobinismo continuaria sendo indispensável, em alguma medida, as restrições às alianças teriam de ser observadas, como expliquei anteriormente, mas eu teria podido explorar muito mais a divisão entre a boa e a má polícia, em benefício de nossa política de reforma, que era, afinal de contas, uma política de revalorização das próprias instituições e dos próprios policiais. 